\title{
DEVELOPMENT AND VALIDATION OF A FAST, SIMPLE, COST-EFFECTIVE AND ROBUST HPLC METHOD FOR LISINOPRIL DETERMINATION IN SOLID PHARMACEUTICAL DOSAGE FORMS
}

\author{
Tanja Bakovska Stoimenova ${ }^{1,2}$, Marjan Piponski ${ }^{2}$, Gordana Trendovska Serafimovska ${ }^{2}$, \\ Marina Stefova ${ }^{1}$ \\ ${ }^{1}$ Institute of Chemistry, Faculty of Natural Sciences and Mathematics, \\ Ss. Cyril and Methodius University, Skopje, Republic of Macedonia \\ ${ }^{2}$ Replek Farm Ltd, Quality Control Department, Skopje, Republic of Macedonia
}

\begin{abstract}
A fast, simple, cost-effective and robust chromatographic method was developed and validated for determination of the antihypertensive drug lisinopril dihydrate in tablets under routine operational conditions, without ion-pair reagents, high column temperatures and an acidic mobile phase. Taking into consideration all four different $\mathrm{p} K_{\mathrm{a}}$ values of lisinopril, the separation was optimized using the C18 column (end-capped, $150 \mathrm{~mm} \times 4.6 \mathrm{~mm} 5 \mu \mathrm{m}$ ) and a mobile phase composed of methanol and ammonium (or potassium) dihydrogen phosphate buffer ( $\mathrm{pH} \mathrm{7.2)} \mathrm{with} \mathrm{a} \mathrm{flow} \mathrm{rate} \mathrm{of} 1.1 \mathrm{ml} / \mathrm{min}$, UV detection at $214 \mathrm{~nm}$ and a temperature of $40{ }^{\circ} \mathrm{C}$. These optimized conditions led to the production of a single and symmetrical peak for lisinopril. This mobile phase is suitable for different HPLC columns, which makes it appropriate for industrial quality control laboratories. The developed method was validated, showing excellent validation results and the possibility to be implemented for the determination of lisinopril in combined dosage forms with other active substances.
\end{abstract}

Keywords: lisinopril dihydrate; tablets; HPLC; optimization; validation

\section{РАЗВОЈ И ВАЛИДАЦИЈА НА БРЗ, ЕДНОСТАВЕН, ЕКОНОМИЧЕН И РОБУСТЕН НРLС-МЕТОД ЗА ОПРЕДЕЛУВАњЕ НА ЛИЗИНОПРИЛ ВО ЦВРСТИ ФАРМАЦЕВТСКИ ДОЗИРАНИ ФОРМИ}

Развиен е и валидиран брз, едноставен, економичен и робустен хроматографски метод за определување на антихипертензивниот лек лизиноприл дихидрат во таблети, кој е погоден за примена во рутинска контрола бидејќи не вклучува употреба на реагенси со јонски парови, високи температури на колоната и кисела мобилна фаза. Имајќи ги предвид сите четири различни вредности на $\mathrm{p} K_{\mathrm{a}}$ на лизиноприл, хроматографското разделување е оптимизирано со употреба на колоната С18 (специјално деактивирана, [анг. end-capped], $150 \mathrm{~mm} \times 4.6 \mathrm{~mm} 5 \mu \mathrm{m}$ ) и мобилна фаза составена од метанол и амониум (или калиум) дихидрогенфосфатен пуфер (pH 7,2) со проток од $1,1 \mathrm{ml} / \mathrm{min}, \mathrm{UV}$ детекција на бранова должина од $214 \mathrm{~nm}$ и температура на колоната од $40{ }^{\circ} \mathrm{C}$. При овие утврдени најдобри услови се добива еден симетричен пик од лизиноприл. Оваа мобилна фаза е погодна за употреба со различни HPLC колони, што ја прави соодветна за лаборатории за контрола на квалитет во индустријата. Развиениот метод е валидиран при што се добиени одлични резултати кои овозможуваат негова имплементација за определување на лизиноприл во комбинирани дозирани форми заедно со други активни супстанци.

Клучни зборови: лизиноприл дихидрат; таблети; HPLC; оптимизација; валидација 


\section{INTRODUCTION}

Lisinopril dihydrate (Fig. 1) is a member of the group of antihypertensive drugs from the ACE (angiotensin converting enzyme) inhibitors class, defined in the European pharmacopoeia [1] as 1-[N[(s)-1-carboxy-3-phenylpropyl]-L-lysyl]-L-proline dihydrate, with the IUPAC name: (2S)-1-[(2S)-6amino-2-[[(1S)-1-carboxy-3-phenylpropyl]amino] hexanoyl]pyrrolidine-2-carboxylic acid. It was the third ACE inhibitor (after captopril and enalapril) that was introduced into therapy in the early 1990s [2]. Despite this, lisinopril is still one of the most commonly prescribed and used ACE inhibitors, being among the first three best buy ACEIs for high blood pressure treatment, and it is a best buy drug for most people who need an ACEI after a heart attack, taking the cost and convenience into account [3]. Among the analytical methods for the determination of lisinopril, HPLC methods are the usual methods of choice [1, 4-15]. Besides HPLC, some UV-spectrophotometric and spectrofluorometric methods, without [16] or with the derivatization of lisinopril [7, 17-23] or using derivative spectrophotometry $[24,25]$, can also be applied, but these methods are very restrictive and not preferred in pharmaceutical analysis. Lisinopril dihydrate has UV absorbance maximum in the low UV region at wavelengths of about $210-220 \mathrm{~nm}$, which complicates its UV spectral analysis because of the interferences of other components present in pharmaceutical formulations.

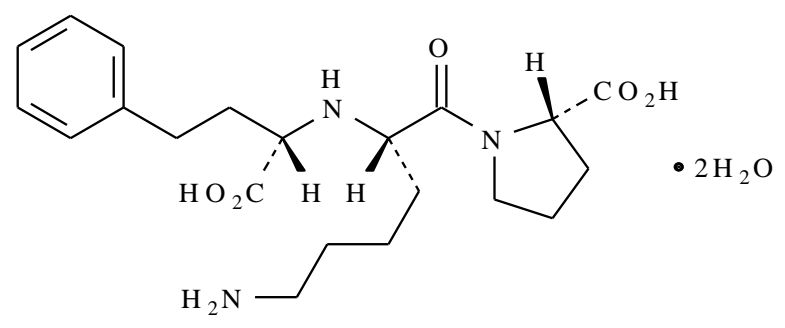

Fig. 1. Chemical structure of lisinopril dihydrate

The presence of the proline moiety complicates the HPLC determination of lisinopril dihydrate, causing peak splitting or extensive peak tailing, which is often solved by using alkyl-sulfonate ion-pair reagents (most frequently hexanesulfonate, and rarely heptansulfonate or octansulfonate). The use of ion-pair reagents in HPLC methods for lisinopril determination is almost always accompanied by high column temperatures and low $\mathrm{pH}$ values of mobile phases, which are the three well known RP bonded phase column de- stroyers. Even in the three Pharmacopoeias, EP [1], BP [4] and USP [5], quantification methods for lisinopril prescribe the use of hexanesulfonate and phosphate buffer ( $\mathrm{pH} 2.0$ ) in the mobile phase and a column temperature of $50{ }^{\circ} \mathrm{C}$, to avoid lisinopril peak splitting and tailing. Very low $\mathrm{pH}$ and high temperatures are not recommended by the majority of column vendors. Moreover, the use of ion-pair reagents permanently changes the column characteristics and reserves its use only for ion pair employing separations.

There are diverse published HPLC methods that make use of the above-mentioned critical parameters: mobile phases in a wide $\mathrm{pH}$ region, from 2 to 7.5, with or without the use of ion-pair reagents and column temperatures from ambient up to $60{ }^{\circ} \mathrm{C}$. Rao and Rani [10] used a Kromasil C18, $250 \mathrm{~mm} \times 4.6 \mathrm{~mm}$ column at $50{ }^{\circ} \mathrm{C}$ with UV detection at $210 \mathrm{~nm}$, a mobile phase composed of acetonitrile and phosphate buffer without precisely defined $\mathrm{pH}$ value $(4: 96, \mathrm{v} / \mathrm{v})$, with a flow rate of 1 $\mathrm{ml} / \mathrm{min}$, and obtained a symmetrical peak with a retention time of 9.217 minutes; Adam et al. [12] developed and validated a method using a Waters Spherisorb C18 column, $250 \mathrm{~mm} \times 4.6 \mathrm{~mm}$, with 5 $\mu \mathrm{m}$ particles, signal monitoring at $210 \mathrm{~nm}$, a mobile phase composed of tetrabutyl ammonium hydroxide solution $(\mathrm{pH} 6.5 ; 0.03 \mathrm{M})$ and acetonitrile $(4: 1, \mathrm{v} / \mathrm{v})$, a flow rate of $1.0 \mathrm{ml} / \mathrm{min}$, and the separation was completed within 3.49 minutes; Raju and Rao [13] proposed a method using a C8 XTerra $150 \mathrm{~mm} \times 4.6 \mathrm{~mm}$ column with $3.5 \mu \mathrm{m}$ particles, UV detection at $215 \mathrm{~nm}$ with a mobile phase consisting of potassium dihydrogen phosphate buffer $(0.7 \%, \mathrm{w} / \mathrm{v})$ with triethylamine $(0.2 \%, \mathrm{w} / \mathrm{v})$ $(\mathrm{pH} 3.0)$ and methanol (35:65, v/v), which led to an early eluting time for lisinopril of 2.3 minutes, with a flow rate of $0.8 \mathrm{ml} / \mathrm{min}$; Chander et al. [14] published a method for lisinopril determination with use of Nucleosil $125 \mathrm{~mm} \times 4 \mathrm{~mm}$ column with $5 \mu \mathrm{m}$ particles as the stationary phase and a mobile phase consisting of buffer solution, isopropyl alcohol and triethylamine $(95: 5: 0.1, \mathrm{v} / \mathrm{v} / \mathrm{v})$ at a flow rate of $1.0 \mathrm{ml} / \mathrm{min}$, column temperature of 50 ${ }^{\circ} \mathrm{C}$ and detection at $215 \mathrm{~nm}$, with a run time of 7 min; and Maslarska and Tencheva [15] used a Lichrospher $\mathrm{C} 18,250 \mathrm{~mm} \times 4 \mathrm{~mm}$ column with 10 $\mu \mathrm{m}$ particles, a mobile phase composed of acetonitrile and phosphate buffer ( $\mathrm{pH} 2.0)$ at $35{ }^{\circ} \mathrm{C}$ and UV detection at $215 \mathrm{~nm}$.

After a review of the methods developed for the determination of lisinopril using reversed phase columns, the aim of this study was to develop and validate an appropriate HPLC method that enables the efficient separation of lisinopril and will avoid 
the use of any of the above-mentioned conditions that are considered harmful for HPLC columns.

\section{EXPERIMENTAL}

\subsection{Chemicals and reagents}

All of the chemicals used were EP grade. Methanol, acetonitrile, and ammonium dihydrogen phosphate $\left(\mathrm{NH}_{4} \mathrm{H}_{2} \mathrm{PO}_{4}\right)$ were purchased from Carlo Erba, France, $25 \%$ ammonium hydroxide solution and $85 \%$ o-phosphoric acid were purchased from Sigma-Aldrich, USA, potassium dihydrogen phosphate $\left(\mathrm{KH}_{2} \mathrm{PO}_{4}\right)$ and $37 \%$ hydrochloric acid were purchased from Merck, Darmstadt, Germany, $30 \%$ hydrogen peroxide was purchased from Alkaloid, Macedonia, and sodium hydroxide was purchased from Riedel-de Haën, Germany. The demineralized water with conductivity less than $1 \mu \mathrm{S}$ was produced by a Stilman apparatus.

The standard substance of lisinopril (with potency of $100.09 \%$ and water content of $8.65 \%$, standardized versus reference standard) and Lisinopril tablets were obtained from Replek Farm Ltd., Skopje, Macedonia.

\subsection{Preparation of solutions}

Samples and standards for dissolution testing of Lisinopril tablets were prepared in $0.1 \mathrm{M}$ hydrochloric acid, to a final, working concentration of $0.01 \mathrm{mg}$ lisinopril $/ \mathrm{ml}$.

Samples and standards for assay and the uniformity of dosage unit testing of Lisinopril tablets were prepared in diluent composed of water and methanol $(75: 25, \mathrm{v} / \mathrm{v})$, in a final working concentration of $0.1 \mathrm{mg}$ lisinopril $/ \mathrm{ml}$.

Placebo solutions, in both cases, were suitably prepared from the excipients present in the tablet formulation.

\subsection{Equipment}

\subsubsection{Instruments}

Samples were weighed using OHAUS Pioneer $^{\mathrm{TM}}$ balance with an accuracy of $0.1 \mathrm{mg}$. For $\mathrm{pH}$ adjustment of the mobile phase buffer, a HANNA Instruments HI113 $\mathrm{pH}$ meter was used.

Four HPLC systems were used. Three were used for method development and the optimization of experimental parameters, while the fourth was used for method validation of the finally defined method:
- UPLC system Shimadzu Nexera XR with low pressure mixing quaternary pump, autosampler, column oven, controller and PDA detector, controlled by Lab Solutions software;

- UHPLC Dionex Ultimate 3000 with low pressure mixing quaternary pump, autosampler, column oven and four channel UV-Vis detector and Chromeleon software;

- HPLC Varian ProStar with ternary high pressure mixing pump, autosampler with column oven and Photo Diode Array detector, controlled by software Varian-Star;

- HPLC Agilent Technologies 1200 series with low pressure mixing quaternary pump, autosampler, column oven, controller and PDA and ion trap MS detector, controlled by ChemStation software.

\subsubsection{Analytical columns}

The following HPLC columns were tested: Purospher C18e STAR $125 \mathrm{~mm} \times 4 \mathrm{~mm}, 5 \mu \mathrm{m}$ particles, Lichrospher $100 \mathrm{C} 18 \mathrm{e} 125 \mathrm{~mm} \times 4 \mathrm{~mm}$, $5 \mu \mathrm{m}$ particles and Purospher C18e STAR $150 \mathrm{~mm}$ $\times 4.6 \mathrm{~mm}, 5 \mu \mathrm{m}$ particles, all used with $4 \mathrm{~mm} \times 4$

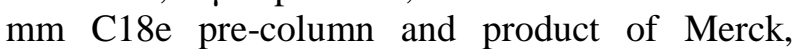
Darmstadt, Germany; Discovery C18 $100 \mathrm{~mm} \times$ $4.6 \mathrm{~mm}, 5 \mu \mathrm{m}$ particle size (Supelco, Bellefonte, USA); Nucleosil C18 $250 \mathrm{~mm} \times 4.6 \mathrm{~mm}, 10 \mu \mathrm{m}$ particles (Macherey-Nagel, Germany); RP Select B $75 \mathrm{~mm} \times 4 \mathrm{~mm}, 5 \mu \mathrm{m}$ particle size and Purospher C8 $55 \mathrm{~mm} \times 4 \mathrm{~mm}, 5 \mu \mathrm{m}$ particle size (Merck, Darmstadt, Germany).

\section{RESULTS AND DISCUSSION}

\subsection{Method development and optimization}

The method development started with the selection of the most appropriate buffer to be used as a mobile phase constituent. For this purpose, the four different $\mathrm{p} K_{\mathrm{a}}$ values for lisinopril were considered: $\mathrm{p} K_{\mathrm{a} 1}=2.5, \mathrm{p} K_{\mathrm{a} 2}=4.0, \mathrm{p} K_{\mathrm{a} 3}=6.7$ and $\mathrm{p} K_{\mathrm{a} 4}=10.1$ [26]. Chromatographic theory suggests avoiding the $\mathrm{pH}$ of mobile phases in the proximity of the $\mathrm{pK}_{\mathrm{a}}$ values of analytes, if possible up to at least \pm 1 $\mathrm{pH}$ unit [27]. The widest interval is between $\mathrm{p} K_{\mathrm{a} 3}$ and $\mathrm{p} K_{\mathrm{a} 4}$, which seemed a good option, and this $\mathrm{pH}$ range was also the least investigated and used for this purpose. The concept was to test alkaline mobile phases with a $\mathrm{pH}$ value no higher than 7.5, which is below the upper recommended limit for extended chromatographic column life and to use, for the majority of standards, nominal bonded 
phase $\mathrm{C} 18$ and $\mathrm{C} 8$ matrices, in order to achieve the applicability of the method for as much variety of HPLC columns as possible.

Two buffer solutions were tested with the same $\mathrm{pH}$ value of 7.2: $20 \mathrm{mM}$ potassium dihydrogen phosphate and $20 \mathrm{mM}$ ammonium dihydrogen phosphate buffer solution, adjusted to $\mathrm{pH} 7.2$ with sodium hydroxide and ammonium hydroxide, respectively. The increase in the $\mathrm{pH}$ value of mixtures of buffers with methanol of about $0.15 \mathrm{pH}$ units for every $10 \%$ methanol present in the mixture [28] was taken into consideration. The use of the much more soluble ammonium dihydrogen phosphate was preferred in combination with the more miscible methanol, compared to acetonitrile, especially in buffers with $\mathrm{pH}$ higher than 6, when the solubility of binary mobile phase exponentially decreases.

The other limiting factor that had to be kept in mind was the low wavelength $(\sim 215 \mathrm{~nm})$ at which lisinopril shows maximum absorbance, which restricts the use of mobile phase components with high UV cut-off values, such as inorganic buffers or organic modifiers and tailing correcting additives that absorb at low wavelengths. Therefore, the use of buffering components like acetate, citrate and formate as well as tetrahydrofuran and triethylamine as tailing correctors should have been avoided. So, the conclusion was to use a stable, UV transparent buffer such as a phosphate buffer combined with methanol.

As a result, the goal was to obtain a symmetrical chromatographic peak of lisinopril, using a mobile phase with $\mathrm{pH}$ 7-7.5 without using ion pair reagents and column heating, even though previous studies $[29,30]$ demonstrated that these factors cause isomerization, i.e. rotamerization of lisinopril leading to splitting and/or tailing of the obtained chromatographic peak.

Since the choice of an appropriate RP column is very important, the high purity, base deactivated and end-capped silica based matrices gave better results (Fig. 2, Tab. 1). That is why, from all of the tested columns, Purospher STAR RP18e 150 $\mathrm{mm} \times 4.6 \mathrm{~mm}, 5 \mu \mathrm{m}$, the column that gave a chromatographic peak with best symmetry, was finally chosen to be used for method validation. Nevertheless, the method was shown to be equally applicable with $\mathrm{C} 18$ and $\mathrm{C} 8$ bonded reversed phase columns (Table 1). The choice of $\mathrm{C} 18$ as the preferred column was also based on the well documented stability of longer alkyl-chains attached to silica matrices in alkaline mobile phases and longer analyte retention which increases the column capacity.

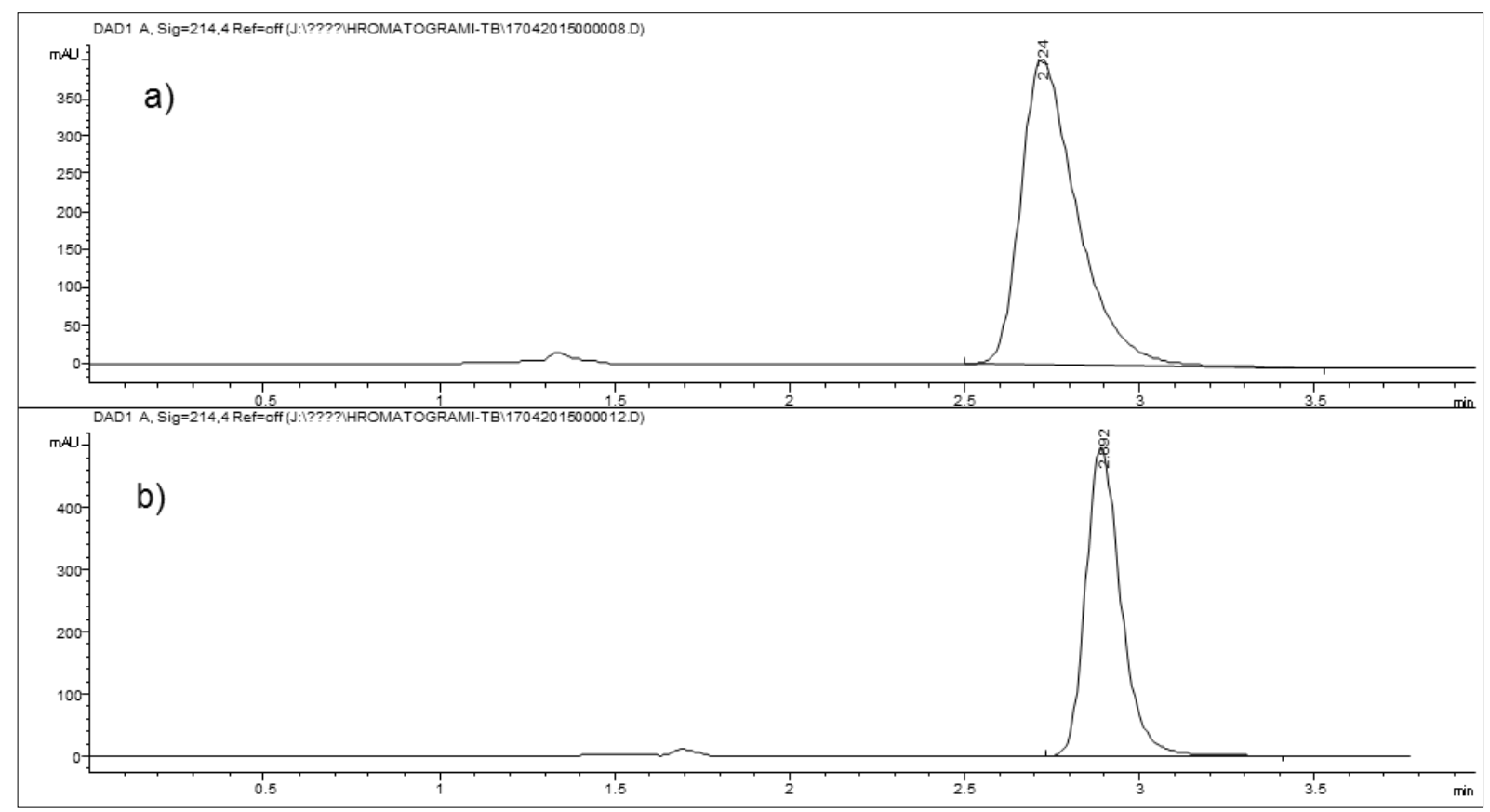

Fig. 2. Chromatograms obtained using: a) Lichrospher $100 \mathrm{C} 18 \mathrm{e} 125 \mathrm{~mm} \times 4 \mathrm{~mm}, 5 \mu \mathrm{m}$ HPLC column; symmetry factor 1.521(USP); in order to achieve the same RT of lisinopril as when using the finally proposed HPLC column, mobile phase composition and flow rate were suitably changed: ammonium dihydrogen phosphate buffer $(\mathrm{pH} 7.2 ; 20 \mathrm{mM})$ and methanol $(65: 35, \mathrm{v} / \mathrm{v})$, with a flow rate of $0.8 \mathrm{ml} / \mathrm{min}$; b) Purospher STAR RP18e $150 \mathrm{~mm} \times 4.6 \mathrm{~mm}, 5 \mu \mathrm{m}$ HPLC column, ammonium dihydrogen phosphate buffer $(\mathrm{pH} 7.2 ; 20 \mathrm{mM})$ and methanol $(60: 40, \mathrm{v} / \mathrm{v})$, with a flow rate of $1.1 \mathrm{ml} / \mathrm{min}$, was finally chosen and proposed for use; symmetry factor 1.285 (USP). 
Table 1

System suitability results obtained with different types of tested HPLC columns

\begin{tabular}{lcc}
\hline \hline HPLC column & $\begin{array}{c}\text { Number of theoretical } \\
\text { plates (per column) }\end{array}$ & $\begin{array}{c}\text { Lisinopril peak } \\
\text { symmetry* }\end{array}$ \\
\hline Purospher STAR RP18e $150 \mathrm{~mm} \times 4.6 \mathrm{~mm}, 5 \mu \mathrm{m}$ & 4083 & 1.29 \\
Purospher STAR C18e $125 \mathrm{~mm} \times 4 \mathrm{~mm}, 5 \mu \mathrm{m}$ & 1496 & 1.35 \\
Lichrospher 100 C18e $125 \mathrm{~mm} \times 4 \mathrm{~mm}, 5 \mu \mathrm{m}$ & 1562 & 1.52 \\
Discovery C18 $100 \mathrm{~mm} \times 4.6 \mathrm{~mm}, 5 \mu \mathrm{m}$ & 3297 & 1.33 \\
Purospher C8 $55 \mathrm{~mm} \times 4 \mathrm{~mm}, 5 \mu \mathrm{m}$ & 1690 & 1.27 \\
\hline \hline
\end{tabular}

*Calculated according to USP

Finally, the proposed method uses Purospher STAR RP18e $150 \mathrm{~mm} \times 4.6 \mathrm{~mm}, 5 \mu \mathrm{m}$ HPLC column, thermostated at $40{ }^{\circ} \mathrm{C}$, with a mobile phase composed of ammonium dihydrogen phosphate buffer $(\mathrm{pH} 7.2 ; 20 \mathrm{mM})$ and methanol $(60: 40, \mathrm{v} / \mathrm{v})$, with a flow rate of $1.1 \mathrm{ml} / \mathrm{min}$, signal monitoring at $214 \mathrm{~nm}$ and an injection volume $20 \mu \mathrm{l}$. These HPLC conditions can be used for dissolution, assay and uniformity of dosage unit testing for various strengths of Lisinopril tablets.

The retention factor $\left(k^{\prime}\right)$ of the peak of lisinopril using this HPLC column and conditions is $\sim 0.75$. Although it is lower than 1 , it yields satisfying results in respect to all validation parameters and allows shorter analysis times.
This method was completely validated according to the ICH guidelines for the validation of analytical procedures Q2 (R1) [31].

\subsection{Method validation}

\subsubsection{Selectivity}

In order to demonstrate the selectivity of the developed method, chromatograms of placebo, standard and test solutions, prepared suitably as for dissolution and assay testing of lisinopril, were analyzed. No interference was detected between the solvent or placebo components with the chromatographic peak originating from the active substance, lisinopril, with a retention time of 3.0 minutes (Fig. 3).

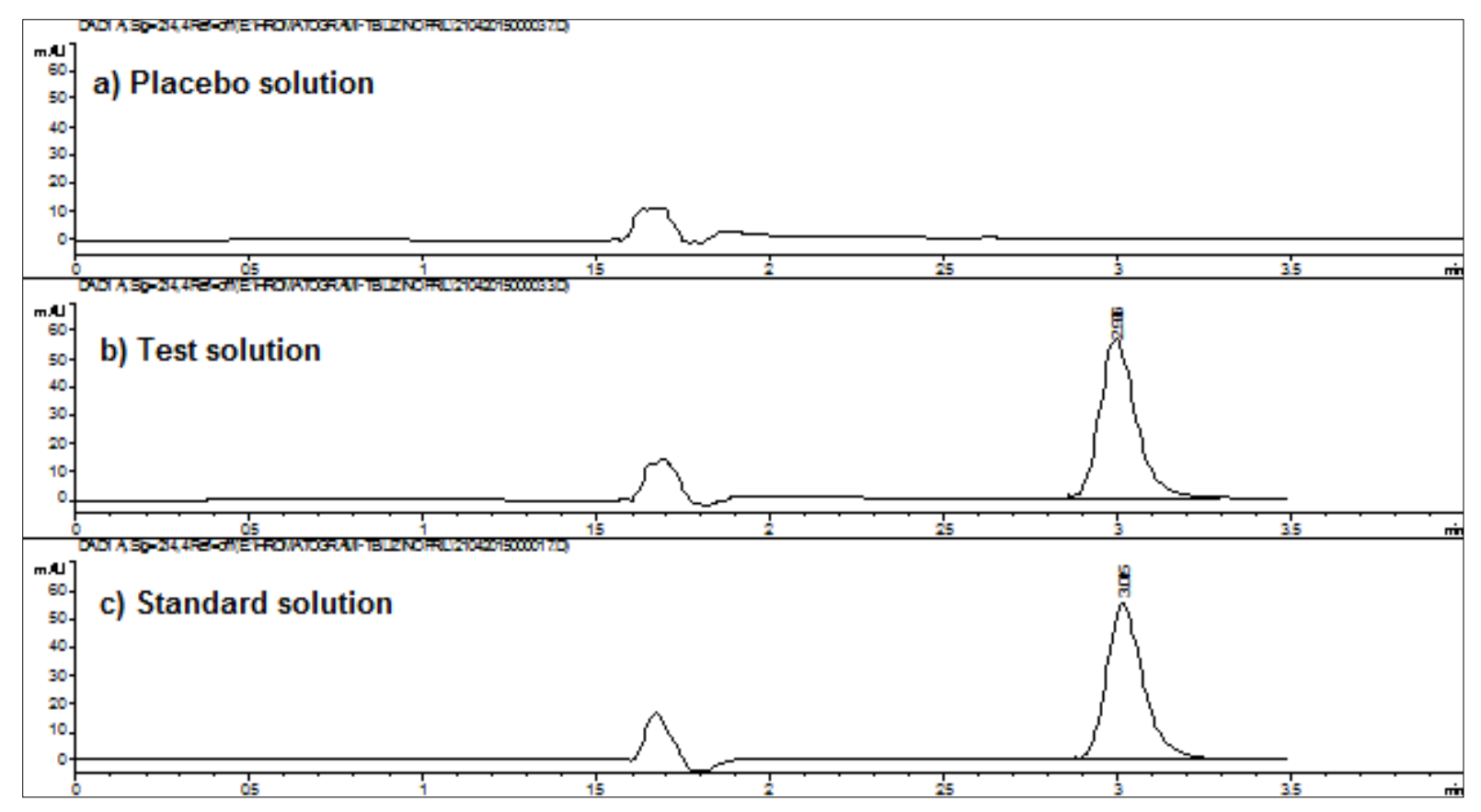

Fig. 3. Selectivity of the method for dissolution testing of Lisinopril tablets:

a) Placebo solution; b) Test solution with concentration approximately $0.01 \mathrm{mg}$ lisinopril $/ \mathrm{ml}$;

c) Standard solution with concentration $0.01 \mathrm{mg}$ lisinopril $/ \mathrm{ml}$ 
Furthermore, forced degradation studies were performed under the following conditions: tablet powder treated for 24 hours with $0.1 \mathrm{M}$ $\mathrm{NaOH}$ (base hydrolysis), $0.1 \mathrm{M} \mathrm{HCl}$ (acid hydrolysis) and $3 \% \mathrm{v} / \mathrm{v}_{2} \mathrm{O}_{2}$ (oxidation). After 24 hours, all of the prepared samples were neutralized and diluted to a final concentration of $0.1 \mathrm{mg}$ lisinopril $/ \mathrm{ml}$. These solutions were then analyzed with the developed HPLC method. There were no interferences detected between the degradation products of lisinopril obtained during the performed forced degradation study, and the active substance itself. Only oxidative degradation yielded a few degradation products during this time. All of the detected peaks from the degradation products are well separated from the lisinopril peak (Fig. 4). PDA analysis of the lisinopril peak showed that the peak is pure in all three cases and that the proposed method is selective for lisinopril determination. Peak purity factor calculated by ChemStation software of Agilent HPLC for the peak of lisinopril, in all three performed degradation studies, is greater than 999.96 .

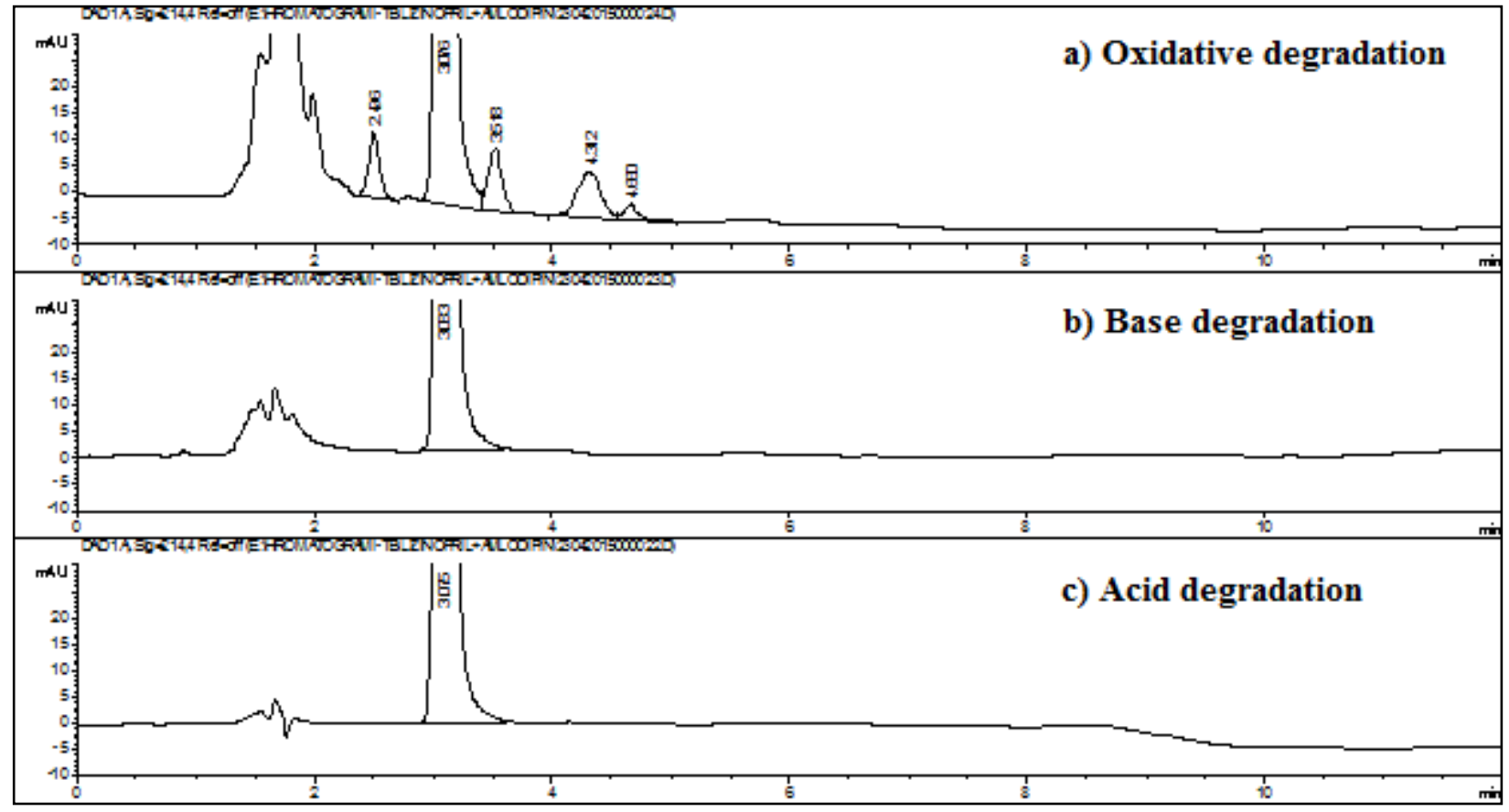

Fig. 4. Chromatograms obtained from forced degradation studies performed on Lisinopril tablets, during a time period of 24 hours: a) Oxidation with $3 \% \mathrm{v} / \mathrm{v} \mathrm{H}_{2} \mathrm{O}_{2}$; b) Base hydrolysis with $0.1 \mathrm{M} \mathrm{NaOH}$; and c) Acid hydrolysis with $0.1 \mathrm{M} \mathrm{HCl}$

\subsubsection{Accuracy}

The accuracy of the method was examined using 9 determinations over three concentration levels in the interval between $50 \%$ and $150 \%$ of the working concentration for dissolution and assay and uniformity of dosage units testing of Lisinopril tablets, i.e. between $0.005 \mathrm{mg} / \mathrm{ml}$ and 0.015 $\mathrm{mg} / \mathrm{ml}$ for dissolution testing and $0.05 \mathrm{mg} / \mathrm{ml}$ and $0.15 \mathrm{mg} / \mathrm{ml}$ for assay and uniformity of dosage unit testing. The analytical procedure was applied to synthetic mixtures of the drug product components with known added amounts of the active substance, corresponding to these concentration levels. Obtained recovery in both cases was between $98 \%$ and $102 \%$, the RSD of the obtained results was lower than $1 \%$ and the correlation coefficient $(R)$ and the slope were almost ideal ( 1.0) (Tab. 2).

\subsubsection{Precision}

The precision of the method was tested from the aspects of system repeatability, method repeatability and intermediate precision. System repeatability was tested by performing 6 replicate injections of the standard solutions for dissolution and assay and the uniformity of dosage unit testing of Lisinopril tablets. RSD values of the obtained peak areas were lower than $1 \%$ in both cases $(\mathrm{RSD}=$ 0.33 for the dissolution testing method and RSD = 0.17 for the assay and uniformity of dosage unit testing method). 
Table 2

Accuracy of the method for dissolution and assay/uniformity of dosage unit testing of Lisinopril tablets

\begin{tabular}{cll}
\hline \hline Approximate level & $\begin{array}{c}\text { Recovery (\%) for dissolution testing } \\
(n=3)\end{array}$ & $\begin{array}{c}\text { Recovery (\%) for assay/uniformity } \\
\text { of dosage units testing }(n=3)\end{array}$ \\
\hline $50 \%$ & 101.44 & 99.41 \\
$100 \%$ & 101.51 & 98.96 \\
$150 \%$ & 101.44 & 99.61 \\
& & \multicolumn{1}{c}{ RSD $=0.33$} \\
& RSD $=0.27$ & Correlation coefficient $(R)=0.9999$ \\
& Correlation coefficient $(R)=0.9999$ & Slope $=0.9969$ \\
\hline
\end{tabular}

Method repeatability was demonstrated by preparing 6 individual test solutions, from the same homogenous sample. The RSD value from the obtained $\%$ of dissolved or present active substance was calculated and was lower than $2 \%$ in both cases $(\mathrm{RSD}=0.36$ for the dissolution testing method and RSD $=1.11$ for the assay and uniformity of dosage units testing method).

The intermediate precision of the method for determination of the quantity of lisinopril/tablet was also proven, since the RSD value of the percent obtained of 12 test solutions prepared on two different days (6 test solutions in the first day, for method repeatability testing, and another 6 test solutions prepared in the second day, from the same homogenous sample) was found to be $1.1 \%$.

\subsubsection{Linearity and range}

Linearity of the method for dissolution testing was proven for five concentration levels in the range between $40 \%$ (corresponding to $\mathrm{c} \sim 0.004$ $\mathrm{mg} / \mathrm{ml}$ ) and $150 \%$ (corresponding to $\mathrm{c} \sim 0.015$ $\mathrm{mg} / \mathrm{ml}$ ) from the working concentration. All concentration levels were prepared with suitable dilutions of the standard solution prepared with concentrations of $0.02 \mathrm{mg} / \mathrm{ml}$ which is two times higher than the working concentration, $0.01 \mathrm{mg} / \mathrm{ml}$. RSD of the obtained response factors was much lower than $2 \%(0.29 \%)$, the linearity regression equation was $y=37.71 x-1.31$ and the correlation coefficient obtained was ideal, $R^{2}=1.0000$.

Linearity of the method for assay and uniformity of dosage units testing was also checked and confirmed in five concentration levels in the range between $50 \%$ (corresponding to $\mathrm{c} \sim 0.05$ $\mathrm{mg} / \mathrm{ml}$ ) and $150 \%$ (corresponding to $\mathrm{c} \sim 0.15$ $\mathrm{mg} / \mathrm{ml}$ ) from the working concentration. All concentration levels were prepared with suitable dilutions of the standard solution prepared with a concentration of $0.2 \mathrm{mg} / \mathrm{ml}$, which is two times higher than the working concentration, $0.1 \mathrm{mg} / \mathrm{ml}$. The RSD of the obtained response factors was much lower than $2 \%(0.10 \%)$, linearity regression equation was $y=37.87 x-1.10$ and the correlation coefficient obtained was ideal in this case as well, $R^{2}=$ 1.0000 .

\subsubsection{Stability of the standard solutions}

It was confirmed that the standard solutions are stable and can be used for up to 24 hours after preparation. The difference between peak areas of the standard solution for dissolution testing of Lisinopril tablets immediately after preparation and after 24 hours is less than $2 \%$ (0.84\% exactly). The difference between peak areas of the standard solution for assay and uniformity of dosage units testing of Lisinopril tablets, immediately after preparation and after 24 hours, is also less than 2 $\%(0.95 \%$ exactly).

\subsubsection{Filter study}

A filter study was also conducted in order to determine whether the type of filter used would have an impact on the final result. The test solution for assay and uniformity of dosage unit testing, before filling in a vial, was filtered through a 0.45 $\mu \mathrm{m}$ Nylon filter and through a $0.45 \mu \mathrm{m} \mathrm{RC}(\mathrm{Re}-$ generated cellulose) filter. The difference between the obtained assay results was minor, $0.56 \%$, which implies that both types of filters can be used during sample preparation without affecting the results.

\subsubsection{Robustness}

The reliability of the analysis with respect to slight variations in method parameters was checked and proven. Robustness testing of the developed HPLC method for the quantification of lisinopril was conducted, by making deliberate changes in the following three HPLC variables: temperature of the column oven $\left( \pm 5{ }^{\circ} \mathrm{C}\right)$, mobile phase flow rate $( \pm 0.2 \mathrm{ml} / \mathrm{min})$ and percentage of methanol in the mobile phase $( \pm 5 \%)$. The impact 
of these changes on the peak area of lisinopril, retention time, peak symmetry and number of theoretical plates, as system suitability parameters, was examined.

By varying the column temperature by $\pm 5{ }^{\circ} \mathrm{C}$ it was concluded that it does not significantly change the system suitability parameters. As expected, the number of theoretical plates increased while retention time decreased with the increased temperature, whereas peak symmetry was best with the prescribed column temperature of $40{ }^{\circ} \mathrm{C}$ (Tab. 3).

Mobile phase flow rate variations of \pm 0.2 $\mathrm{ml} / \mathrm{min}$ also did not cause any significant changes in the system suitability parameters. The number of theoretical plates and retention times slightly decreased with increasing flow rate, while peak symmetry was best with the prescribed flow rate of $1.1 \mathrm{ml} / \mathrm{min}$ (Tab. 3).
By making changes in the methanol content in the mobile phase composition of $\pm 5 \%$ (absolute) from the prescribed content of $40 \%(\mathrm{v} / \mathrm{v})$, it was concluded that with a higher content of methanol, the elution of lisinopril is faster, as expected, but the highest number of theoretical plates and best symmetry factor were obtained using an eluent containing $40 \%$ methanol, as proposed (Tab. 3).

Taking into consideration all of the above presented results from the robustness testing and the fact that many columns with different properties were successfully tested during method development, it can be concluded that the developed method is robust and the measurements and results from the analysis are not susceptible to inaccuracy in cases of intentional or accidental small variations in HPLC conditions.

T a b l e 3

Influence of three HPLC variables: column temperature $\left( \pm 5^{\circ} \mathrm{C}\right)$, mobile phase flow rate $( \pm 0.2 \mathrm{ml} / \mathrm{min})$ and methanol content in the mobile phase composition ( $\pm 5 \%)$, from the prescribed test conditions, on the system suitability parameters

\begin{tabular}{|c|c|c|c|c|c|c|c|c|c|}
\hline & \multicolumn{3}{|c|}{$\begin{array}{c}\text { Variations in } \mathrm{T} \pm 5^{\circ} \mathrm{C} \\
\left(35-45^{\circ} \mathrm{C}\right)\end{array}$} & \multicolumn{3}{|c|}{$\begin{array}{l}\text { Variations in mobile phase flow rate } \\
\qquad \pm 0.2 \mathrm{ml} / \mathrm{min}\end{array}$} & \multicolumn{3}{|c|}{$\begin{array}{l}\text { Variations in } \% \text { of methanol } \\
\text { in mobile phase } \pm 5 \%\end{array}$} \\
\hline & $35^{\circ} \mathrm{C}$ & $40^{\circ} \mathrm{C}$ & $45^{\circ} \mathrm{C}$ & $0.8 \mathrm{ml} / \mathrm{min}$ & $1.1 \mathrm{ml} / \mathrm{min}$ & $1.3 \mathrm{ml} / \mathrm{min}$ & $35 \%$ & $40 \%$ & $45 \%$ \\
\hline $\begin{array}{l}\text { No. of theoretical } \\
\text { plates (per column) }\end{array}$ & 3993 & 4083 & 4155 & 4837 & 4083 & 3533 & 3866 & 4083 & 3922 \\
\hline$t_{\mathrm{r}} / \min$ & 3.144 & 2.986 & 2.921 & 4.377 & 2.986 & 2.525 & 3.698 & 2.986 & 2.631 \\
\hline Peak symmetry & 0.715 & 0.731 & 0.714 & 0.699 & 0.731 & 0.728 & 0.709 & 0.731 & 0.718 \\
\hline
\end{tabular}

\section{CONCLUSION}

The developed HPLC method for the determination of lisinopril can be used for dissolution, assay and uniformity of dosage unit testing of Lisinopril tablets. Its main advantage when compared to other methods developed for this purpose, especially with the pharmacopoeia methods, is in its satisfactory selectivity and peak shape and symmetry obtained without using ion pair reagents, high column temperatures and mobile phases with low $\mathrm{pH}$ values, factors that can shorten the column life cycle or restrict their use. Of great importance is also the fact that it demonstrates that with careful choice and optimization of HPLC conditions, lisinopril peak splitting can be avoided when using a mobile phase with a high $\mathrm{pH}$ value. Finally, it is fast, simple, cost-effective, selective, precise, accurate and robust, and can be used for the routine analysis of Lisinopril tablets in quality control laboratories.

\section{REFERENCES}

[1] European Pharmacopoeia, 8th ed., European Directorate for the Quality of Medicines - Council of Europe, Strasbourg, 2014.

[2] A. Patchett, E. Harris, E. Tristram, M. Wyvratt, M. Wu, D. Taub, E. Peterson, T. Ikeler, J. ten Broeke, L. Payne, D. Ondeyka, E. Thorsett, W. Greenlee, N. Lohr, R. Hoffsommer, H. Joshua, W. Ruyle, J. Rothrock, S. Aster, A. Maycock, F. Robinson, R. Hirschmann, C. Sweet, E. Ulm, D. Gross, T. Vassil, C. Stone, A new class of angiotensin-converting enzyme inhibitors, Nature, 288 (5788), 280-283 (1980).

DOI: http://dx.doi.org/10.1038/288280a0

[3] Consumer Reports Health Best Buy Drugs, Using ACE inhibitors to treat: High blood pressure and heart disease comparing effectiveness, safety and price, Consumers Union of United States, Inc., March 2011.

[4] British Pharmacopoeia Commission, British Pharmacopoeia 2013, The Stationery Office, Norwich, 2012.

[5] United States Pharmacopeia and National Formulary (USP 36-NF 31), United States Pharmacopeia Convention, Rockville, 2012. 
[6] Society of Japanese Pharmacopoeia, Japanese Pharmacopoeia, 16th ed., Tokyo, Maruzen Company Ltd., 2012.

[7] A. El-Gindy, A. Ashour, L. Abdel-Fattah, M. M. Shabana, Spectrophotometric, spectrofluorometric and LC determination of lisinopril, J. Pharm. Biomed. Anal., 25 (5-6), 913-922 (2001).

DOI: http://dx.doi.org/10.1016/S0731-7085(01)00376-4

[8] B. Stanisz, Kinetics of lisiopril degradation in solid phase, React. Kinet. Catal. Lett., 85 (1), 145-152 (2005). DOI: http://dx.doi.org/10.1007/s11144-005-0254-x

[9] C. A. Beasley, J. Shaw, Z. Zhao, R. A. Reed, Development and validation of a stability indicating HPLC method for determination of lisinopril, lisinopril degradation product and parabens in the lisinopril extemporaneous formulation. J. Pharm. Biomed. Anal., 37 (3), 559-567 (2005).

DOI: http://dx.doi.org/10.1016/j.jpba.2004.11.021

[10] S. N. L. Rao, U. N. Rani, Estimation of lisinopril in tablets by RP-HPLC method, Int. J. Chem. Sci., 7 (2), 1462-1466 (2009).

[11] R. Ludwig, Analysis of lisinopril by LC/UV using a core enhanced technology accucore RP-MS column, LCGC ASIA PACIFIC, 14 (3), 38 (2011).

[12] E. Adam, I. Barakat, A. Saeed, Development and validation of a high performance liquid chromatography method for the determination of lisinopril dihydrate, Asian $J$. Pharm. Biol. Res., 2 (2), 94-99 (2012).

[13] V. B. Raju, A. L. Rao, Development, estimation and validation of lisinopril in bulk and its pharmaceutical formulation by HPLC method, E-J. Chem., 9 (1), 340-344 (2012). DOI: http://dx.doi.org/10.1155/2012/292754

[14] V. Chander, M. Mohan, R. Seth, P. Singh, R. Singh, S. Gupta, Development and validation of RP-HPLC method for estimation of lisinopril in tablet dosage form, Anal. Chem. Lett. 2 (5), 309-313 (2012).

DOI: http://dx.doi.org/10.1080/22297928.2012.10648282

[15] V. Maslarska, J. Tencheva, Development of analytical method for determination of lisinopril tablets using RPHPLC method, Int. J. Pharm. Bio. Sci., 4 (4), 163-167 (2013).

[16] N. D. Preetham, K. Sujana, S. D. P. Sankar, Development and validation of UV spectrophotometric method for the estimation of lisinopril in bulk and pharmaceutical formulation, Int. J. Pharm. Sci. Rev. Res., 25 (1), 257-259 (2014).

[17] A. F. El-Yazbi, H. H. Abdine, A. R. Shaalan, Spectrophotometric and spectrofluorometric methods for the assay of lisinopril in single and multicomponent pharmaceutical dosage forms, J. Pharm. Biomed. Anal., 19 (6), 819-827 (1999).

DOI: http://dx.doi.org/10.1016/S0731-7085(98)00110-1

[18] G. Paraskevas, J. Atta-Politou, M. Koupparis, Spectrophotometric determination of lisinopril in tablets using 1-fluoro-2,4-dinitrobenzene reagent, J. Pharm. Biomed. Anal., 29 (5), 865-872 (2002).

DOI: http://dx.doi.org/10.1016/S0731-7085(02)00207-8
[19] S. E. Aktas, L. Ersoy, O. Sagirli, A new spectrofluorimetric method for the determination of lisinopril in tablets, II Farmaco 58 (2), 165-168 (2003). DOI: http://dx.doi.org/10.1016/S0014-827X(02)00013-7

[20] A. A. El-Emam, S. H. Hansen, M. A. Moustafa, S. M. El-Ashry, D. T. El-Sherbiny, Determination of lisinopril in dosage forms and spiked human plasma through derivatization with 7-chloro-4-nitrobenzo-2-oxa-1,3-diazole (NBD-Cl) followed by spectrophotometry or HPLC with fluorimetric detection, J. Pharm. Biomed. Anal., 34 (1), 35-44 (2004).

DOI: http://dx.doi.org/10.1016/j.japna.2003.08.021

[21] N. Rahman, N. Anwar, M. Kashif, Application of $\pi$ acceptors to the spectrophotometric determination of lisinopril in commercial dosage forms, II Farmaco, 60 (67), 605-611 (2005). DOI: http://dx.doi.org/10.1016/j.farmac.2005.04.011

[22] A. Raza, M. T. Ansari, Atta-ur-Rehman, Spectrophotometric determination of lisinopril in pure and pharmaceutical formulations, J. Chin. Chem. Soc., 52 (5), 10551059 (2005). DOI: $10.1002 /$ jccs. 200500149

[23] M. C. Jamakhandi, C. Javali, I. J. Disouza, S. U. Chougule, K. A. Mullani, Spectrophotometric determination of lisinopril dosage form by condensation reaction, Int. J. Pharm. Sci., 3 (2), 185-187 (2011).

[24] D. Özer, H. Senel, Determination of lisinopril from pharmaceutical preparations by derivative UV spectrometry, $J$. Pharm. Biomed. Anal., 21 (3), 691-695 (1999). DOI: http://dx.doi.org/10.1016/S0731-7085(99)00168-5

[25] B. Stanisz, Estimation of the applicability of differential spectroscopic method for the determination of lisinopril in tablets and for the evaluation of its stability, Acta Pol. Pharm., 61 (5), 327-334 (2004).

[26] M. Remko, Acidity, lipophilicity, solubility, absorption and polar surface area of some ACE inhibitors, Chem. Pap.-Chem. Zvesti, 61 (2), 133-141 (2007). DOI: http://dx.doi.org/10.2478/s11696-007-0010-y

[27] Technical overview, Control pH during Method Development for Better Chromatography, Agilent Technologies Inc., USA, 2015.

[28] Y. Kazakevich, R. Lobrutto (Editors), HPLC for Pharmaceutical Scientists, John Wiley \& Sons, New Jersey, USA, 2007.

[29] A. Kocijan, R. Grahek, D. Kocijan, L. Kralj-Zupančič, Effect of column temperature on the behaviour of some angiotenzin converting enzyme inhibitors during highperformance liquid chromatographic analysis, J. Chromatogr. B: Biomed. Sci. Appl., 755 (1-2), 229-235 (2001). DOI: http://dx.doi.org/10.1016/S0378-4347(01)00082-2

[30] S. Bouabdallah, H. Trabelsi, K. Bouzouita, S. Sabbah, Reversed-phase liquid chromatography of lisinopril conformers, J. Biochem. Biophys. Methods, 54 (1-3), 391405 (2002).

DOI: http://dx.doi.org/10.1016/S0165-022X(02)00140-9

[31] International Conference on Harmonization ( $\mathrm{ICH})$ of technical requirements for registration of pharmaceuticals for human use, Validation of analytical procedures: Text and methodology Q2(R1), ICH, Geneva, Switzerland, 2005. 